Article

\title{
Straightforward One-Pot Synthesis of New 4-Phenyl-1,2,5,6-tetraazafluoranthen-3(2H)-one Derivatives: $X$-ray Single Crystal Structure and Hirshfeld Analyses
}

\author{
Ahmed T. A. Boraei ${ }^{1, *}$, Matti Haukka ${ }^{2}$ D , Manar Sopaih ${ }^{1}$, Abdullah Mohammed Al-Majid ${ }^{3}$, Saied M. Soliman ${ }^{4}$ (D) \\ Assem Barakat $^{3, *(D)}$ and Ahmed A. M. Sarhan ${ }^{5}$ \\ 1 Chemistry Department, Faculty of Science, Suez Canal University, Ismailia 41522, Egypt; \\ mnrsopaih@yahoo.com \\ 2 Department of Chemistry, University of Jyväskylä, P.O. Box 35, FI-40014 Jyväskylä, Finland; \\ matti.o.haukka@jyu.fi \\ 3 Department of Chemistry, College of Science, King Saud University, P.O. Box 2455, \\ Riyadh 11451, Saudi Arabia; amajid@ksu.edu.sa \\ 4 Department of Chemistry, Faculty of Science, Alexandria University, Alexandria 21321, Egypt; \\ saeed.soliman@alexu.edu.eg \\ 5 Chemistry Department, Faculty of Science, Arish University, Al-Arish 45511, Egypt; asarhan@aru.edu.eg \\ * Correspondence: ahmed_boraei@science.suez.edu.eg (A.T.A.B.); ambarakat@ksu.edu.sa (A.B.); \\ Tel.: +966-11467-5901 (A.T.A.B.); Fax: +966-11467-5992 (A.B.)
}

check for updates

Citation: Boraei, A.T.A.; Haukka, M.; Sopaih, M.; Al-Majid, A.M.; Soliman, S.M.; Barakat, A.; Sarhan, A.A.M. Straightforward One-Pot Synthesis of New 4-Phenyl-1,2,5,6-

tetraazafluoranthen-3(2H)-one

Derivatives: X-ray Single Crystal Structure and Hirshfeld Analyses. Crystals 2022, 12, 262. https:// doi.org/10.3390/ cryst12020262

Academic Editor: Klaus Merz

Received: 29 January 2022

Accepted: 11 February 2022

Published: 15 February 2022

Publisher's Note: MDPI stays neutral with regard to jurisdictional claims in published maps and institutional affiliations.

Copyright: (C) 2022 by the authors. Licensee MDPI, Basel, Switzerland. This article is an open access article distributed under the terms and conditions of the Creative Commons Attribution (CC BY) license (https:// creativecommons.org/licenses/by/ $4.0 /)$.

\begin{abstract}
A straightforward one-pot route for the synthesis of a new 4-phenyl-1,2,5,6-tetraazafluoranthen$3(2 \mathrm{H})$-one is reported form the direct hydrazinolysis of triketo ester and hydrazine hydrate in ethanol. 4-Phenyl-1,2,5,6-tetraazafluoranthen-3(2H)-one was subjected to $a z a$-Michael addition and $\mathrm{N}$-alkylation on reaction with a set of alkylating agents in the presence of $\mathrm{K}_{2} \mathrm{CO}_{3}$. Hydrazinolysis of 4-phenyl-1,2,5,6-tetraazafluoranthen-3(2H)-one ester to hydrazide and conversion of hydrazide to thiosemicarbazide were successful. X-Ray single crystals analysis and ${ }^{1} \mathrm{H},{ }^{13} \mathrm{C}$ NMR were used for unambiguous structure confirmation. The $\mathrm{O} \ldots \mathrm{H}, \mathrm{N} \ldots \mathrm{H}, \mathrm{C} \ldots \mathrm{N}$ and $\mathrm{C} \ldots \mathrm{C}$ in 2 , and the $\mathrm{N} \ldots$ $\mathrm{H}, \mathrm{C} \ldots \mathrm{N}, \mathrm{C} \ldots \mathrm{C}, \mathrm{C} \ldots \mathrm{O}$ and $\mathrm{H} \ldots \mathrm{H}$ interactions in $\mathbf{6}$ are the most important in the molecular packing based on Hirshfled analysis. Moreover, the presence of short C . . C and C . N contacts in both compounds revealed the presence of $\pi-\pi$ stacking interactions.
\end{abstract}

Keywords: fluoranthenes; polycyclic aromatic heterocycles; aza-Michael addition; N-alkylation; Hirshfeld Analyses

\section{Introduction}

Polycyclic aromatic heterocycles are a class of chemicals include multi-ring aromatic compounds. In particular, fluoranthenes [1-3] are an example of four fused aromatic heterocycles which recentlyreceived a lot of attention, because this core structure has remarkable applications such as organic electronics [4]. Fluoranthene is a building block which was found in many natural products, for example, daldinone E (fungus Daldinia sp.) [5], and hortein (which is a fungus Hortaea werneckii associated with the sponge Aplysina aerophoba) [6]. In a different application of fluoranthenes which was discovered as fluorescent probe (FLUN-550) is a new class of live cell permeant, nontoxic, selective staining and intracellular lipid droplets quantifications based fluoranthenes [7].

Design and synthesis of new substituted of fluoranthenes have been gaining a lot of interest in the last decade. The synthetic roads for this interesting scaffold reported in the literatures though transition metal mediated [8-19] or Diels-Alder reactions [20-23].

Indeed, the palladium compound, $\operatorname{Pd}_{2}(\mathrm{dba})_{3}(20 \mathrm{~mol} \%)$ was employed as active catalyst for the reaction between 1,8-dichloronaphthalenes and arylboronic acid at elevated temperature (up to $175^{\circ} \mathrm{C}$ ) to afford the fluoranthenes derivatives [24]. Another approach 
that utilized the Pd-catalyst system was achieved for the synthesis of fluoranthenes which proceeded via three steps based on the inter- and intramolecular C-H arylation [25].

The Suzuki-Miyaura reaction also is considered one of the synthetic protocols for the synthesis of fluoranthenes derivatives initiating form 1,8-diiodonaphthalene in the presence of palladium catalysts [26]. Koutentis et al. also explored the chemistry of this interesting scaffold which synthesized the $a z a$-analogues by the oxidative and non-oxidative cyclization approach [27]. Other approaches employed the silica sulphuric acid: a reusable solid catalyst for one pot synthesis of densely substituted pyrrole-fused isocoumarins under solvent-free conditions [28].

Recently, Boraei et al. have demonstrated a green and straightforward method for the synthesis of tatraazafluoranthenones starting from ninhydrin and ethyl acetoacetate $(\beta$-ketoesters) in water as a green solvent [29].

In this article, we are validating the application of our previous published method and used other $\beta$-ketoesters (ethyl benzoylacetate) and ninhydrin for the synthesis of new tatraazafluoranthenone analogues in straightforward, one-pot free catalyst route (Figure 1).

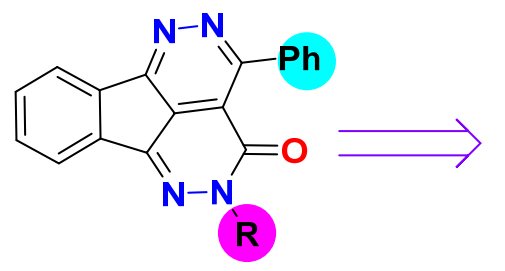

$N$-alkylated tetraazafluoranthen-3(2H)-one

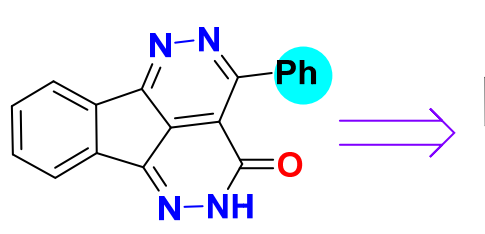<smiles>CCOC(=O)C(C(=O)c1ccccc1)C1(O)C(=O)c2ccccc2C1=O</smiles>

tetraazafluoranthen-3(2H)-one

\section{Triketo ester}

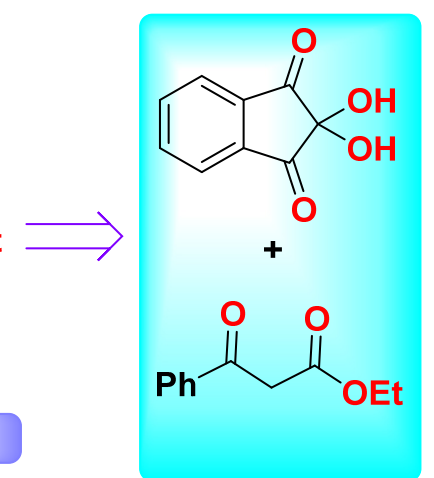

Figure 1. Retro-synthesis of the fluoranthenes.

\section{Materials and Methods}

General Information

"Stuart Melting Point apparatus [SMP10], Bibby Scientific Ltd., (Wilmington, DE, USA) was used for measuring melting points in open capillaries and were uncorrected. Monitoring of reactions progress was done using TLC Merck aluminum-precoated silica gel plates $\left(60 \AA, F_{254}\right)$. Product spot visualization was achieved using UV light. NMR spectra were detected using Bruker spectrometer at $400 \mathrm{MHz}$ for ${ }^{1} \mathrm{H}$ NMR and at $100 \mathrm{MHz}$ for ${ }^{13} \mathrm{C}$ NMR calibrated by (TMS, 0 ppm) as internal standard" (Supplementary Materials).

Synthesis of Ethyl 2-(2-hydroxy-1,3-dioxo-2,3-dihydro-1H-inden-2-yl)-3-oxo-3phenylpropanoate (1)

This compound was synthesized and characterized according to the reported procedures [30,31].

Synthesis of 4-Phenyl-1,2,5,6-tetraazafluoranthen-3(2H)-one (2)

A mixture of triketo ester $\mathbf{1}$ [6.4 g, $18.2 \mathrm{mmol}]$ and hydrazine hydrate [3.0 $\mathrm{mL}]$ was heated under refluxed in ethanol [10.0 mL] until ppt appeared (about 0.5-1 our). The reaction mixture cooled to room temperature and the formed solid was filtered, dried, and recrystallized from $\mathrm{DMF} / \mathrm{EtOH}$.

Yield (3.0 g, 55\%), m.p. $>300{ }^{\circ} \mathrm{C} .{ }^{1} \mathrm{H}$ NMR (400 MHz, DMSO- $\left.d_{6}\right) \delta 13.22(\mathrm{~s}, 1 \mathrm{H}), 8.23$ $(\mathrm{d}, J=6.3 \mathrm{~Hz}, 1 \mathrm{H}), 7.99(\mathrm{~d}, J=8.0 \mathrm{~Hz}, 1 \mathrm{H}), 7.93(\mathrm{~d}, J=7.9 \mathrm{~Hz}, 2 \mathrm{H}), 7.69-7.68(\mathrm{~m}, 2 \mathrm{H})$, 7.55-7.54 (m, 3H); ${ }^{13} \mathrm{C}$ NMR (100 MHz, DMSO- $\left.d_{6}\right) \delta 158.1,157.9,157.1,145.0,137.3,135.8$, $135.7,132.9,131.7,130.6,130.4,128.2,127.6,123.8,123.1,118.9$; Elemental analysis (CHN) calculated for $\left[\mathrm{C}_{18} \mathrm{H}_{10} \mathrm{~N}_{4} \mathrm{O}\right]: \mathrm{C}, 72.48, \mathrm{H}, 3.38, \mathrm{~N}, 18.78, \mathrm{O}, 5.36$ found $\mathrm{C}, 72.61, \mathrm{H}, 3.42$, N, 18.65.

Michael Addition procedure 
A mixture of Michael donor $2(0.6 \mathrm{~g}, 2.0 \mathrm{mmol})$ and Michael acceptor-acrylonitrile $(0.12 \mathrm{~g}, 2.2 \mathrm{mmol})$ was refluxed in ethanol $(10.0 \mathrm{~mL})$ containing $\mathrm{Et}_{3} \mathrm{~N}(0.31 \mathrm{~mL}, 2.2 \mathrm{mmol})$ for $6 \mathrm{~h}$. The mixture was cooled, the solid was filtered, and recrystallized from ethanol.

3-(3-Oxo-4-phenyl-1,2,5,6-tetraazafluoranthen-2(3H)-yl)propanenitrile (3)

Yield (0.55 g, 77\%), m.p. 229-230 ${ }^{\circ} \mathrm{C} .{ }^{1} \mathrm{H}$ NMR (400 MHz, DMSO-d 6 ) $\delta 8.26(\mathrm{~s}, 1 \mathrm{H})$, $8.02(\mathrm{~s}, 1 \mathrm{H}), 7.91(\mathrm{~s}, 2 \mathrm{H}), 7.72(\mathrm{~s}, 2 \mathrm{H}), 7.57(\mathrm{~s}, 3 \mathrm{H}), 4.46(\mathrm{~s}, 2 \mathrm{H}), 3.06(\mathrm{~s}, 2 \mathrm{H}) ;{ }^{13} \mathrm{C} \mathrm{NMR}$ $\left(101 \mathrm{MHz}, \mathrm{DMSO}-d_{6}\right) \delta 158.1,157.2,156.7,144.7,137.3,135.5,133.1,132.2,130.6,130.4$, 128.1, 127.2, 124.0, 123.4, 118.9, 118.2, 48.3, 16.9; Elemental analysis (CHN) calculated for $\left[\mathrm{C}_{21} \mathrm{H}_{13} \mathrm{~N}_{5} \mathrm{O}\right]: \mathrm{C}, 71.79 ; \mathrm{H}, 3.73 ; \mathrm{N}, 19.93, \mathrm{O}, 4.55$ found $\mathrm{C}, 71.81 ; \mathrm{H}, 3.83 ; \mathrm{N}, 19.71$.

Alkylation procedure

A mixture of tetraazafluoranthen-3(2H)-one $2(0.6 \mathrm{~g}, 2.0 \mathrm{mmol})$ and $\mathrm{K}_{2} \mathrm{CO}_{3}(0.3 \mathrm{~g}, 2.2 \mathrm{mmol})$, in equal volumes of dry acetone/DMF $(10 \mathrm{~mL})$ was stirred for one hour, then alkyl halide $(2.2 \mathrm{mmol}$ ) was added portion wise, and the reaction mixture was left on stirring overnight (the reaction is monitored by TLC and reflux is fixed if reaction did not complete). Then, the solvent was removed, water was added for complete precipitation and the formed solid was collected by filtration, dried, and recrystallized from EtOH or DMF/EtOH.

2-Allyl-4-phenyl-1,2,5,6-tetraazafluoranthen-3(2H)-one (4)

Yield (0.54 g, 79\%), m.p. 190-191 ${ }^{\circ} \mathrm{C} .{ }^{1} \mathrm{H}$ NMR (400 MHz, $\left.\mathrm{CDCl}_{3}\right) \delta 8.34-8.26$ (m, 1H), 7.99-7.98 (m, 3H), 7.66-7.54 (m, 5H), 6.13-6.04 (m, 1H), $5.37(\mathrm{~d}, J=17.2 \mathrm{~Hz}, 1 \mathrm{H}), 5.30$ $(\mathrm{d}, J=10.2 \mathrm{~Hz}, 1 \mathrm{H}), 4.91(\mathrm{~d}, J=5.9 \mathrm{~Hz}, 2 \mathrm{H}) ;{ }^{13} \mathrm{C}$ NMR $\left(101 \mathrm{MHz}, \mathrm{CDCl}_{3}\right) \delta 158.1,157.5$, 156.3, 144.7, 137.3, 135.5, 134.8, 132.2, 131.8, 131.4, 130.5, 130.3, 128.0, 126.8, 124.00, 123.0, 119.1, 117.6, 55.6; Elemental Analysis calculated for $\left[\mathrm{C}_{21} \mathrm{H}_{14} \mathrm{~N}_{4} \mathrm{O}\right]$ : C, 74.54; $\mathrm{H}, 4.17 ; \mathrm{N}, 16.56$, $\mathrm{O}, 4.73$ found $\mathrm{C}, 74.69 ; \mathrm{H}, 4.30 ; \mathrm{N}, 16.61$.

2-Benzyl-4-phenyl-1,2,5,6-tetraazafluoranthen-3(2H)-one (5)

Yield (0.64 g, 83\%), m.p. 224-225 ${ }^{\circ} \mathrm{C} .{ }^{1} \mathrm{H}$ NMR (400 MHz, DMSO-d 6 ) $\delta 8.24(\mathrm{~s}, 1 \mathrm{H})$, $8.00(\mathrm{~s}, 1 \mathrm{H}), 7.88(\mathrm{~s}, 2 \mathrm{H}), 7.69(\mathrm{~s}, 2 \mathrm{H}), 7.55(\mathrm{~s}, 3 \mathrm{H}), 7.39(\mathrm{~s}, 2 \mathrm{H}), 7.31(\mathrm{~d}, J=19.8 \mathrm{~Hz}, 3 \mathrm{H})$, 5.41 (s, 2H); $\left.{ }^{13} \mathrm{C} \mathrm{NMR} \mathrm{(101} \mathrm{MHz,} \mathrm{DMSO-d}{ }_{6}\right) \delta 158.2,157.3,156.8,144.8,137.4,137.2,135.7$, 132.9, 132.0, 130.6, 130.3, 128.9, 128.1, 127.9, 127.3, 123.9, 123.3, 118.4, 56.0; Elemental Analysis calculated for $\left[\mathrm{C}_{25} \mathrm{H}_{16} \mathrm{~N}_{4} \mathrm{O}\right]$ : $\mathrm{C}, 77.30 ; \mathrm{H}, 4.15 ; \mathrm{N}, 14.42, \mathrm{O}, 4.12$ found $\mathrm{C}, 77.43 ; \mathrm{H}$, $4.21 ; \mathrm{N}, 14.31$.

2-Pentyl-4-phenyl-1,2,5,6-tetraazafluoranthen-3(2H)-one (6)

Yield (0.45 g, 61\%), m.p. ${ }^{116-117 ~}{ }^{\circ} \mathrm{C} .{ }^{1} \mathrm{H}$ NMR $\left(400 \mathrm{MHz}, \mathrm{CDCl}_{3}\right) \delta 8.29-8.28(\mathrm{~m}$, $1 \mathrm{H}), 7.99-7.97(\mathrm{~m}, 3 \mathrm{H}), 7.65-7.54(\mathrm{~m}, 5 \mathrm{H}), 4.29(\mathrm{t}, J=7.5 \mathrm{~Hz}, 2 \mathrm{H}), 1.95-1.74(\mathrm{~m}, 2 \mathrm{H})$, $1.41-1.40(\mathrm{~m}, 4 \mathrm{H}), 0.93(\mathrm{t}, J=6.0 \mathrm{~Hz}, 3 \mathrm{H}) ;{ }^{13} \mathrm{C} \mathrm{NMR}\left(101 \mathrm{MHz}, \mathrm{CDCl}_{3}\right) \delta 158.1,157.5,156.4$, 144.2, 137.2, 135.7, 134.9, 132.2, 131.3, 130.4, 130.3, 128.0, 126.6, 124.0, 122.8, 117.5, 53.4, 28.9, 28.5, 22.4, 14.0; Elemental analysis $(\mathrm{CHN})$ calculated for $\left[\mathrm{C}_{23} \mathrm{H}_{20} \mathrm{~N}_{4} \mathrm{O}\right]: \mathrm{C}, 74.98 ; \mathrm{H}, 5.47 ; \mathrm{N}$, 15.21, O, 4.34 found $\mathrm{C}, 75.11 ; \mathrm{H}, 5.63 ; \mathrm{N}, 15.30$.

Ethyl 2-(3-oxo-4-phenyl-1,2,5,6-tetraazafluoranthen-2(3H)-yl)acetate (7)

Yield (0.63 g, 81\%), m.p. $189-190{ }^{\circ} \mathrm{C} .{ }^{1} \mathrm{H} \mathrm{NMR}\left(400 \mathrm{MHz}, \mathrm{CDCl}_{3}\right) \delta 8.31(\mathrm{~d}, J=7.1 \mathrm{~Hz}, 2 \mathrm{H})$, 7.99-7.96 (m, 3H), 7.75-7.53 (m, 4H), $4.96(\mathrm{~s}, 2 \mathrm{H}), 4.27(\mathrm{q}, J=7.1 \mathrm{~Hz}, 2 \mathrm{H}), 1.26(\mathrm{t}, J=7.1 \mathrm{~Hz}, 3 \mathrm{H})$; ${ }^{13} \mathrm{C} \mathrm{NMR}\left(101 \mathrm{MHz}, \mathrm{CDCl}_{3}\right) \delta 168.0,158.1,157.4,156.8,145.3,137.5,135.2,134.7,132.3,131.8$, 130.5, 130.3, 128.0, 127.3, 124.1, 123.2, 117.6, 62.0, 52.8, 14.2; Elemental Analysis calculated for $\left[\mathrm{C}_{22} \mathrm{H}_{16} \mathrm{~N}_{4} \mathrm{O}_{3}\right]$ : $\mathrm{C}, 68.74 ; \mathrm{H}, 4.20 ; \mathrm{N}, 14.58, \mathrm{O}, 12.49$ found $\mathrm{C}, 68.88 ; \mathrm{H}, 4.14 ; \mathrm{N}, 14.41$.

Synthesis of 2-(3-Oxo-4-phenyl-1,2,5,6-tetraazafluoranthen-2(3H)-yl)acetohydrazide (8)

Tetraazafluoranthen-3 $(2 \mathrm{H})$-one ethyl ester $7(0.77 \mathrm{~g}, 2.0 \mathrm{mmol})$ and hydrazine hydrate $80 \%(2.0 \mathrm{~mL})$ was refluxed in ethanol $(10 \mathrm{~mL})$ for 2 hours, left to cool, the formed solid product was collected by filtration, dried, and recrystallized from EtOH.

Yield (0.67 g, 90\%), m.p. 287-288 ${ }^{\circ} \mathrm{C} .{ }^{1} \mathrm{H}$ NMR (400 MHz, DMSO-d 6$) \delta 9.26(\mathrm{~s}, 1 \mathrm{H})$, 8.30-8.27 (m, 1H), 8.04-8.02 (m, 1H), 7.90-7.87 (m, 2H), 7.74-7.72 (m, 2H), 7.62-7.51 (m, 3H), $4.81(\mathrm{~s}, 2 \mathrm{H}), 4.31(\mathrm{~s}, 2 \mathrm{H}) ;{ }^{13} \mathrm{C}$ NMR $\left(101 \mathrm{MHz}, \mathrm{DMSO}-d_{6}\right) \delta 166.3,158.2,156.9,144.8,137.3$, 135.5, 133.1, 132.2, 130.6, 130.5, 128.2, 127.5, 124.0, 123.4, 118.3, 55.0; Elemental Analysis calculated for $\left[\mathrm{C}_{20} \mathrm{H}_{14} \mathrm{~N}_{6} \mathrm{O}_{2}\right]$ : C, 64.86; H, 3.81; N, 22.69, O, 10.91 found $\mathrm{C}, 64.99 ; \mathrm{H}, 3.93$; $\mathrm{N}, 22.61$. 
Synthesis of 2-(2-(3-Oxo-4-Phenyl-1,2,5,6-tetraazafluoranthen-2(3H)-yl)acetyl)-Nphenylhydrazine-1-carbothioamide (9)

To the tetraazafluoranthene-hydrazide $8(0.74 \mathrm{~g}, 2.0 \mathrm{mmol})$ in ethanol $(10 \mathrm{~mL})$, phenyl isothiocyanate $(0.26 \mathrm{~mL}, 2.2 \mathrm{mmol})$ was added. The mixture was refluxed for 4 hours, then cooled. The solid product was collected by filtration, dried, and recrystallized from $\mathrm{DMF} / \mathrm{EtOH}$.

Yield $(0.82$ g, $82 \%)$, m.p. $>300{ }^{1} \mathrm{H}$ NMR $\left(400 \mathrm{MHz}\right.$, DMSO- $\left.d_{6}\right) \delta 10.40(\mathrm{~s}, 1 \mathrm{H}), 9.82(\mathrm{~s}, 1 \mathrm{H})$, 9.36 (brs, $1 \mathrm{H}), 8.31-8.29(\mathrm{~m}, 1 \mathrm{H}), 8.10-7.95(\mathrm{~m}, 1 \mathrm{H}), 7.94-7.87(\mathrm{~m}, 2 \mathrm{H}), 7.79-7.69(\mathrm{~m}, 2 \mathrm{H})$, 7.66-7.50 (m, 3H), 7.41-7.39 (m, 2H), $7.31(\mathrm{t}, J=7.8 \mathrm{~Hz}, 2 \mathrm{H}), 7.19(\mathrm{t}, J=7.7 \mathrm{~Hz}, 1 \mathrm{H})$, $5.03(\mathrm{~s}, 2 \mathrm{H}) ;{ }^{13} \mathrm{C}$ NMR $\left(101 \mathrm{MHz}, \mathrm{DMSO}-d_{6}\right) \delta 181.0,166.9,158.1,157.2,157.0,144.8,139.3$, 137.2, 135.4, 133.1, 132.2, 130.6, 128.6, 128.2, 127.2, 125.6, 124.0, 123.4, 118.0, 55.6; Elemental Analysis calculated for $\left[\mathrm{C}_{27} \mathrm{H}_{19} \mathrm{~N}_{7} \mathrm{O}_{2} \mathrm{~S}\right]: \mathrm{C}, 64.15 ; \mathrm{H}, 3.79 ; \mathrm{N}, 19.39 ; \mathrm{O}, 6.33 ; \mathrm{S}, 6.34$ found $\mathrm{C}$, 64.31; H, 3.71; N, 19.29; S, 6.37 .

\section{Results and Discussion}

\subsection{Chemistry}

Hydrazinolysis of triketo ester $\mathbf{1}$ by hydrazine hydrate in ethanol under reflux for 0.5-1 h, fascinatingly, gave 4-phenyl-1,2,5,6-tetraazafluoranthen-3(2H)-one 2 in moderate yield (55\%) (Scheme 1). The ${ }^{1} \mathrm{H}$ NMR displayed, in addition to the aromatic proton signals between $\delta 8.23$ and $7.55 \mathrm{ppm}$, a signal at $\delta 13.22 \mathrm{ppm}$ for $\mathrm{NH}$. The ${ }^{13} \mathrm{C}$ NMR showed all carbons between $\delta 158.1$ and $118.9 \mathrm{ppm}$.

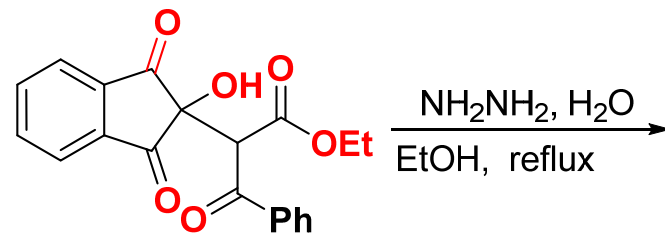<smiles>O=c1[nH]nc2c3c(nnc(-c4ccccc4)c13)-c1ccccc1-2</smiles>

$2,55 \%$

Scheme 1. Synthesis of 4-phenyl-1,2,5,6-tetraazafluoranthen-3(2H)-one 2.

Aza-Michael addition was explored from the addition of $\mathbf{2}$ to acrylonitrile in ethanol and the presences of $\mathrm{Et}_{3} \mathrm{~N}$ to give the Michael adduct 3 in good yield (Scheme 2). The Michael adduct revealed two new signals at $\delta 4.46$ and $3.06 \mathrm{ppm}$ in ${ }^{1} \mathrm{H}$ NMR and their respective carbons appeared at $\delta 48.3$ and $16.9 \mathrm{ppm}$ in ${ }^{13} \mathrm{C}$ NMR which strongly support $a z a$-Michael addition, not $o x a-$ Michael addition.<smiles>O=c1[nH]nc2c3c(nnc(-c4ccccc4)c13)-c1ccccc1-2</smiles>

2

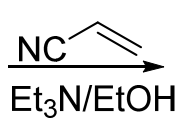

$\mathrm{Et}_{3} \mathrm{~N} / \mathrm{EtOH}$<smiles>N#CCCn1nc2c3c(nnc(-c4ccccc4)c3c1=O)-c1ccccc1-2</smiles>

$3,77 \%$

Scheme 2. Aza-Michael addition of compound 2 to acrylonitrile.

Alkylation of 4-phenyl-1,2,5,6-tetraazafluoranthen-3(2H)-one 2 with allyl bromide, benzyl bromide, amyl bromide, and ethyl chloroacetate was done in acetone/DMF and use of $\mathrm{K}_{2} \mathrm{CO}_{3}$ as proton capturer which led to $\mathrm{N}$-alkylation and formation of aza-alkylated products 4-7 in good yields (Scheme 3 ). The allylated product 4 spectra demonstrated that the allyl group protons as: The $\mathrm{sp}^{2}$ vinylic methine proton $\mathrm{CH}_{2}=\mathrm{CH}$ - appeared as multiplet between 6.13 and $6.14 \mathrm{ppm}$, the vinylic sp ${ }^{2}$ methylene protons $\mathrm{H}_{2} \mathrm{C}=\mathrm{CH}$ - were found as two doublet signals, one of them at $5.37 \mathrm{ppm}$ with coupling constant value $17.2 \mathrm{~Hz}$ for 
the trans proton, and the other was deduced at $5.30 \mathrm{ppm}$ with ${ }^{3} \mathrm{~J}$ value $10.2 \mathrm{~Hz}$ for the cis proton. The allylic sp ${ }^{3}$ methylene protons $\mathbf{N C H}_{2}$ was established as doublet at $4.91 \mathrm{ppm}$. The allylic carbon atom $\mathbf{N C H}_{\mathbf{2}}$ was detected at $\delta 55.6 \mathrm{ppm}$. The benzylated compound 5 showed the benzyl methylene protons as singlet at $5.41 \mathrm{ppm}$ and the corresponding benzylic methylene carbon at $\delta 56.0 \mathrm{ppm}$. The amylated tetraazafluoranthen-3(2H)-one 6 showed the amyl group protons at $\delta 4.29,1.95-1.74,1.41-1.40$, and $0.93 \mathrm{ppm}$ and the respective amyl carbons at $\delta 53.4,28.5,22.4$, and $14.0 \mathrm{ppm}$. The esterified product 7 showed a singlet signal at $4.96 \mathrm{ppm}$ for $\mathbf{N C H}_{2}$, a quartet signal at $\delta 4.29 \mathrm{ppm}$ for $\mathbf{O} \mathbf{C H}_{2}$, and a triplet signal at $\delta 1.26 \mathrm{ppm}$ for $\mathrm{CH}_{3}$. The ${ }^{13} \mathrm{C}$ NMR displayed the carbonyl carbon of the ester group at $\delta 168.0 \mathrm{ppm}$, the $\mathbf{O C H}_{\mathbf{2}}$ at $62.0 \mathrm{ppm}, \mathbf{N C H}_{\mathbf{2}}$ at $\delta 52.8 \mathrm{ppm}$, and $\mathrm{CH}_{3}$ at $\delta 14.2 \mathrm{ppm}$.<smiles>O=c1[nH]nc2c3c(nnc(-c4ccccc4)c13)-c1ccccc1-2</smiles>

2<smiles>[X]C[18O][CH]</smiles>

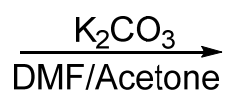<smiles>[R]Cn1nc2c3c(nnc(-c4ccccc4)c3c1=O)-c1ccccc1-2</smiles><smiles>C=CCn1nc2c3c(nnc(-c4ccccc4)c3c1=O)-c1ccccc1-2</smiles><smiles>O=c1c2c(-c3ccccc3)nnc3c2c(nn1Cc1ccccc1)-c1ccccc1-3</smiles>

5, $83 \%$<smiles>CCCCCn1nc2c3c(nnc(-c4ccccc4)c3c1=O)-c1ccccc1-2</smiles>

$6,61 \%$<smiles>CCOC(=O)Cn1nc2c3c(nnc(-c4ccccc4)c3c1=O)-c1ccccc1-2</smiles>

$7,81 \%$

Scheme 3. Aza-alkylation of 4-phenyl-1,2,5,6-tetraazafluoranthen-3(2H)-one2 with a set of alkylating agents.

Reaction of 4-phenyl-1,2,5,6-tetraazafluoranthen-3(2H)-one ester 7 with hydrazine hydrate afforded the hydrazide 8 which was subjected to reaction with phenyl isothiocyanate in ethanol to afford the thiosemicarbazide 9 (Scheme 4). The 4-phenyl-1,2,5,6tetraazafluoranthen-3(2H)-one hydrazide 8 displayed the hydrazide group protons at $\delta 9.26$ and $4.31 \mathrm{ppm}$ for $\mathbf{N H}$ and $\mathbf{N H}_{2}$, respectively, in addition to the $\mathbf{N C H}_{\mathbf{2}}$ protons at $\delta 4.81 \mathrm{ppm}$. The ${ }^{13} \mathrm{C}$ NMR showed the carbonyl carbon of the hydrazide group at $\delta 166.3 \mathrm{ppm}$ and the $\mathbf{N C H}_{2}$ methylene carbon at $\delta 55.0 \mathrm{ppm}$. The 4-phenyl-1,2,5,6-tetraazafluoranthen$3(2 \mathrm{H})$-one thiosemicarbazide 9 showed the three $\mathrm{NH}$ protons signals at $\delta 10.40,9.82$, and $9.36 \mathrm{ppm}$. The respective ${ }^{13} \mathrm{C}$ NMR detected the thiocarbonyl carbon $(\mathrm{C}=\mathrm{S})$ at $\delta 181.0 \mathrm{ppm}$, the carbonyl carbon $(\mathrm{C}=\mathrm{O})$ at $\delta 166.9 \mathrm{ppm}$, and the $\mathbf{N C H}_{\mathbf{2}}$ methylene carbon at $\delta 55.6 \mathrm{ppm}$.

\subsection{X-ray Discerption of Compounds $\mathbf{2}$ and $\mathbf{6}$}

The X-ray structure of $\mathbf{2}$ is presented in Figure 2A. The structure of $\mathbf{2}$ crystallized in the orthorhombic crystal system and Pbca space group with lattice parameters: $a=12.82600(10)$ $\AA, b=7.80290(10) \AA$ and $c=26.6306(2) \AA$, and unit cell volume of 2665.19(4) $\AA 3$ and $Z=8$ (Table 1). There are four fused ring systems which are almost coplanar. The phenyl ring attached to this fused system is twisted from its mean plan by $47.96^{\circ}$ Selected geometric parameters of $\mathbf{2}$ are listed in Table 2. 


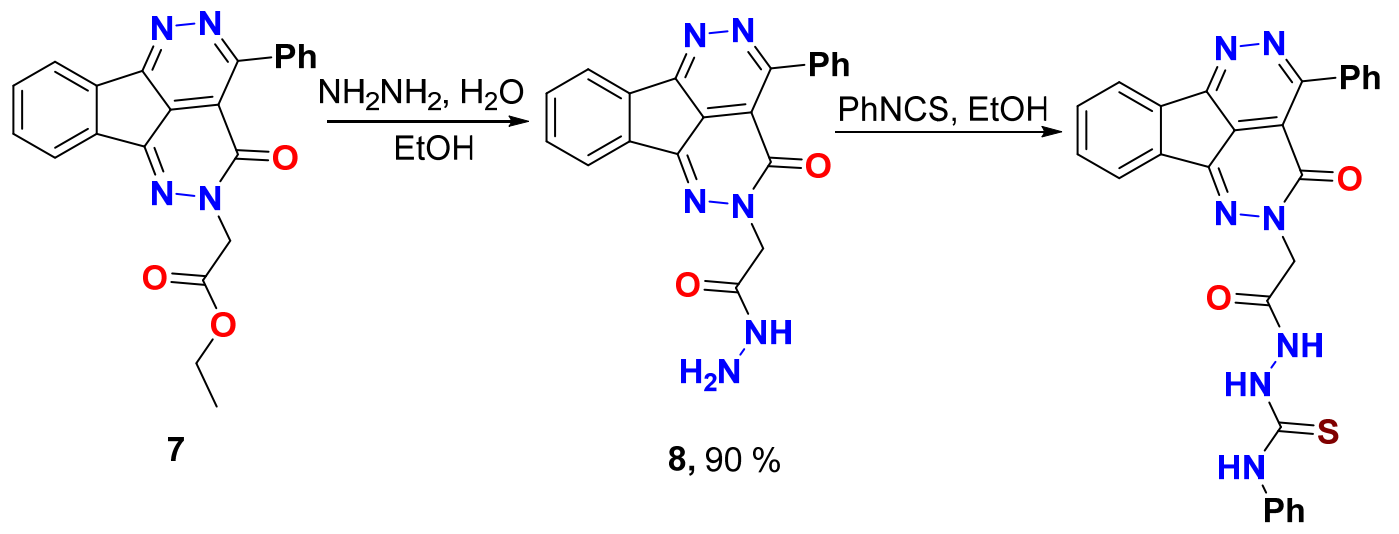

9, $82 \%$

Scheme 4. Hydrazinolysis of 4-phenyl-1,2,5,6-tetraazafluoranthen-3(2H)-one ester and thiosemicarbazide formation.
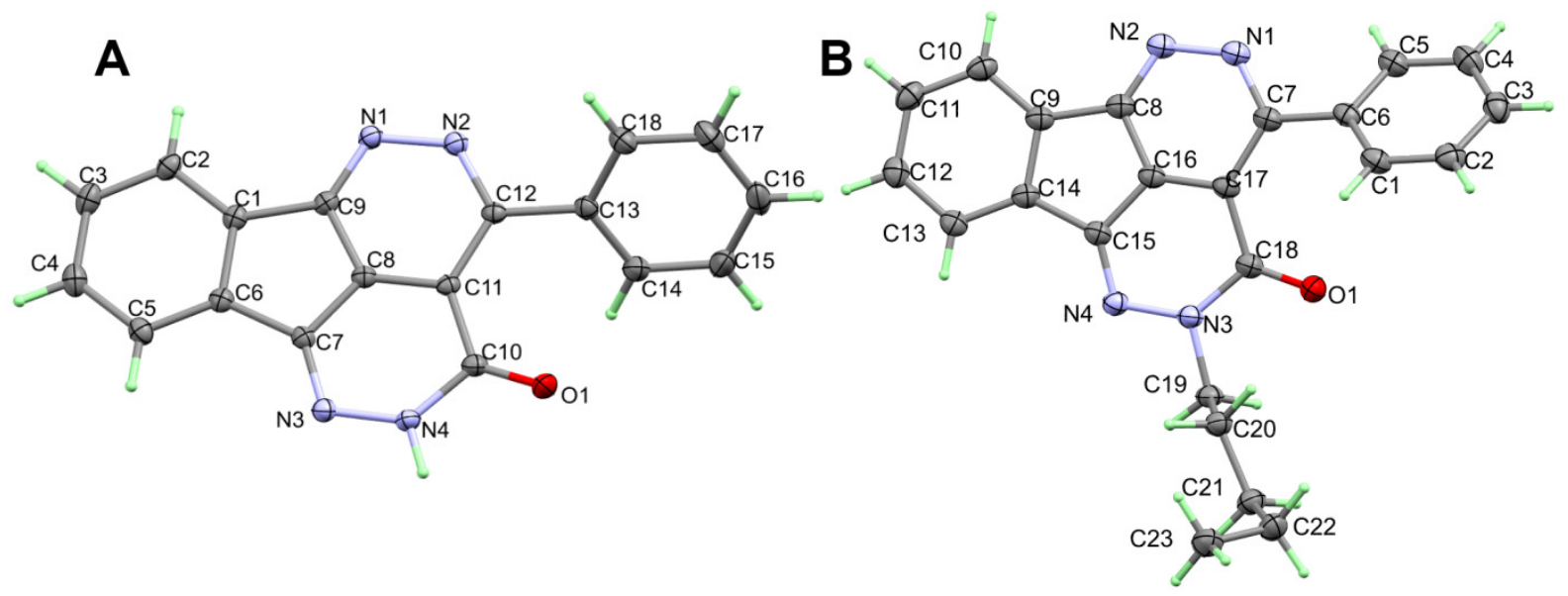

Figure 2. ORTEP of compounds 2 (A) and 6 (B).

The supramolecular structure of 2 is dominated by the N4-H4 ... N1 hydrogen bonding interactions leading to the hydrogen bonding polymer shown in the upper part of Figure 2. The hydrogen bond parameters are listed in Table 3. In addition, the hydrogen bonded chains are stacked to each other via significant amount of $\pi-\pi$ contacts. The shortest $\pi-\pi$ stacking interactions are listed in Table 4 . Hence, the supramolecular structure of 2 could be described by $1 \mathrm{D}$ hydrogen bonding polymer along the b-direction (Figure 3; upper part) combined with $\pi-\pi$ stacking interactions along the a-direction (Figure 3 ; lower part).

The X-ray structure of $\mathbf{6}$ is presented in Figure 2B. The structure of $\mathbf{6}$ crystallized in the less symmetric monoclinic crystal system and $P 2_{1} / c$ space group with lattice parameters: $\mathrm{a}=5.26840(10) \AA, b=15.21900(10) \AA, c=22.7155(2) \AA, \alpha=\gamma=90$ while $\beta=93.6920(10)$ and unit cell volume of 1817.54(4) $\AA 3$ and $Z=4$. Selected geometric parameters of 6 are listed in Table 2. In this case, the mean plane of the almost coplanar fused ring system and the phenyl ring attached to it are twisted from one another by $40.66^{\circ}$. The value of the twist angle is less than that in 2 . The packing in 6 is dominated by $\pi-\pi$ stacking interactions shown in Figure 4 and the shortest interactions between the stacked $\pi$-system are listed in Table 4. 
Table 1. Crystal data of $\mathbf{2}$ and $\mathbf{6}$.

\begin{tabular}{|c|c|c|}
\hline Identification Code & 2 & 6 \\
\hline CCDC & $2,129,954$ & $2,129,955$ \\
\hline empirical formula & $\mathrm{C}_{18} \mathrm{H}_{10} \mathrm{~N}_{4} \mathrm{O}$ & $\mathrm{C}_{23} \mathrm{H}_{20} \mathrm{~N}_{4} \mathrm{O}$ \\
\hline $\mathrm{FW}$ & 298.30 & 368.43 \\
\hline temp $(\mathrm{K})$ & $120(2) \mathrm{K}$ & $120(2)$ \\
\hline$\lambda(\AA)$ & $1.54184 \AA$ & 1.54184 \\
\hline Cryst. Syst. & Orthorhombic & Monoclinic \\
\hline space group & Pbca & $P 2_{1} / c$ \\
\hline$a(\AA)$ & $12.82600(10)$ & $5.26840(10)$ \\
\hline$b(\AA)$ & $7.80290(10)$ & $15.21900(10)$ \\
\hline$c(\AA)$ & $26.6306(2)$ & $22.7155(2)$ \\
\hline$\alpha, \beta, \gamma(\mathrm{deg})$ & $\alpha=\beta=\gamma=90$ & $\begin{array}{c}\alpha=\gamma=90 \\
\beta=93.6920(10)\end{array}$ \\
\hline$V\left(\AA^{3}\right)$ & $2665.19(4)$ & $1817.54(4)$ \\
\hline Z & 8 & 4 \\
\hline$\rho_{\text {calc }}\left(\mathrm{Mg} / \mathrm{m}^{3}\right)$ & 1.487 & 1.346 \\
\hline$\mu(\operatorname{Mo~K} \alpha)\left(\mathrm{mm}^{-1}\right)$ & 0.787 & 0.677 \\
\hline No. reflns. & 37,511 & 46,295 \\
\hline Unique reflns. & 2802 & 3840 \\
\hline Completeness to $\theta=67.684^{\circ}$ & $100 \%$ & $100 \%$ \\
\hline $\operatorname{GOOF}\left(F^{2}\right)$ & 1.057 & 1.052 \\
\hline$R_{\text {int }}$ & 0.0290 & 0.0377 \\
\hline$R_{1}{ }^{\mathrm{a}}(I \geq 2 \sigma)$ & 0.0328 & 0.0356 \\
\hline$w R_{2}{ }^{\mathrm{b}}(I \geq 2 \sigma)$ & 0.0958 & 0.0901 \\
\hline
\end{tabular}

${ }^{\mathrm{a}} R_{1}=\Sigma|| F_{\mathrm{o}}|-| F_{\mathrm{C}}|| / \Sigma\left|F_{\mathrm{o}}\right|{ }^{\mathrm{b}} w R_{2}=\left\{\Sigma\left[w\left(F_{\mathrm{o}}{ }^{2}-{F_{\mathrm{c}}}^{2}\right)^{2}\right] / \Sigma\left[w\left(F_{\mathrm{o}}{ }^{2}\right)^{2}\right]\right\}^{1 / 2}$.

Table 2. Selected bond lengths $[\AA]$ and angles $\left[{ }^{\circ}\right]$ for 2 .

\begin{tabular}{|c|c|}
\hline \multicolumn{2}{|c|}{2} \\
\hline $\mathrm{O}(1)-\mathrm{C}(10)$ & $1.2109(12)$ \\
\hline $\mathrm{N}(1)-\mathrm{C}(9)$ & $1.3153(13)$ \\
\hline $\mathrm{N}(1)-\mathrm{N}(2)$ & $1.3726(12)$ \\
\hline$N(2)-C(12)$ & $1.3361(13)$ \\
\hline $\mathrm{N}(3)-\mathrm{C}(7)$ & $1.3034(14)$ \\
\hline $\mathrm{N}(3)-\mathrm{N}(4)$ & $1.3660(12)$ \\
\hline$N(4)-C(10)$ & $1.4089(12)$ \\
\hline \multicolumn{2}{|c|}{6} \\
\hline $\mathrm{O}(1)-\mathrm{C}(18)$ & $1.2207(13)$ \\
\hline $\mathrm{N}(1)-\mathrm{C}(7)$ & $1.3415(13)$ \\
\hline $\mathrm{N}(1)-\mathrm{N}(2)$ & $1.3709(12)$ \\
\hline $\mathrm{N}(2)-\mathrm{C}(8)$ & $1.3168(13)$ \\
\hline $\mathrm{N}(3)-\mathrm{N}(4)$ & $1.3716(12)$ \\
\hline $\mathrm{N}(3)-\mathrm{C}(18)$ & $1.4137(13)$ \\
\hline$N(3)-C(19)$ & $1.4696(12)$ \\
\hline
\end{tabular}

Table 3. Hydrogen bonds for $2\left[\AA\right.$ and $\left.^{\circ}\right]$.

\begin{tabular}{ccccc}
\hline D-H...A & d(D-H) & d(H...A) & d(D...A) & $<$ (DHA) \\
\hline $\mathrm{N}(4)-\mathrm{H}(4) \ldots \mathrm{N}(1) \# 1$ & $0.927(18)$ & 1.992(18) & $2.9135(12)$ & $172.3(13)$ \\
& \multicolumn{4}{c}{ Symmetry code: \#1 $\mathrm{x}, \mathrm{y}-1, \mathrm{z}$} \\
\hline \multicolumn{4}{c}{} \\
\hline
\end{tabular}


Table 4. $\pi-\pi$ stacking for 2 and $6\left[\AA\right.$ and $\left.^{\circ}\right]$.

\begin{tabular}{|c|c|c|c|}
\hline Contacts & Length & Contacts & Length \\
\hline \multicolumn{2}{|c|}{2} & \multicolumn{2}{|c|}{6} \\
\hline $\mathrm{C} 1 \ldots \mathrm{C} 7$ & 3.387 & $\mathrm{~N} 2 \ldots \mathrm{C} 5$ & 3.195 \\
\hline $\mathrm{C} 1 \ldots \mathrm{C} 8$ & 3.378 & C11 .. C8 & 3.344 \\
\hline C3 . . C10 & 3.334 & C12 . . C15 & 3.303 \\
\hline C6 ... C9 & 3.337 & C14 ... C18 & 3.301 \\
\hline
\end{tabular}

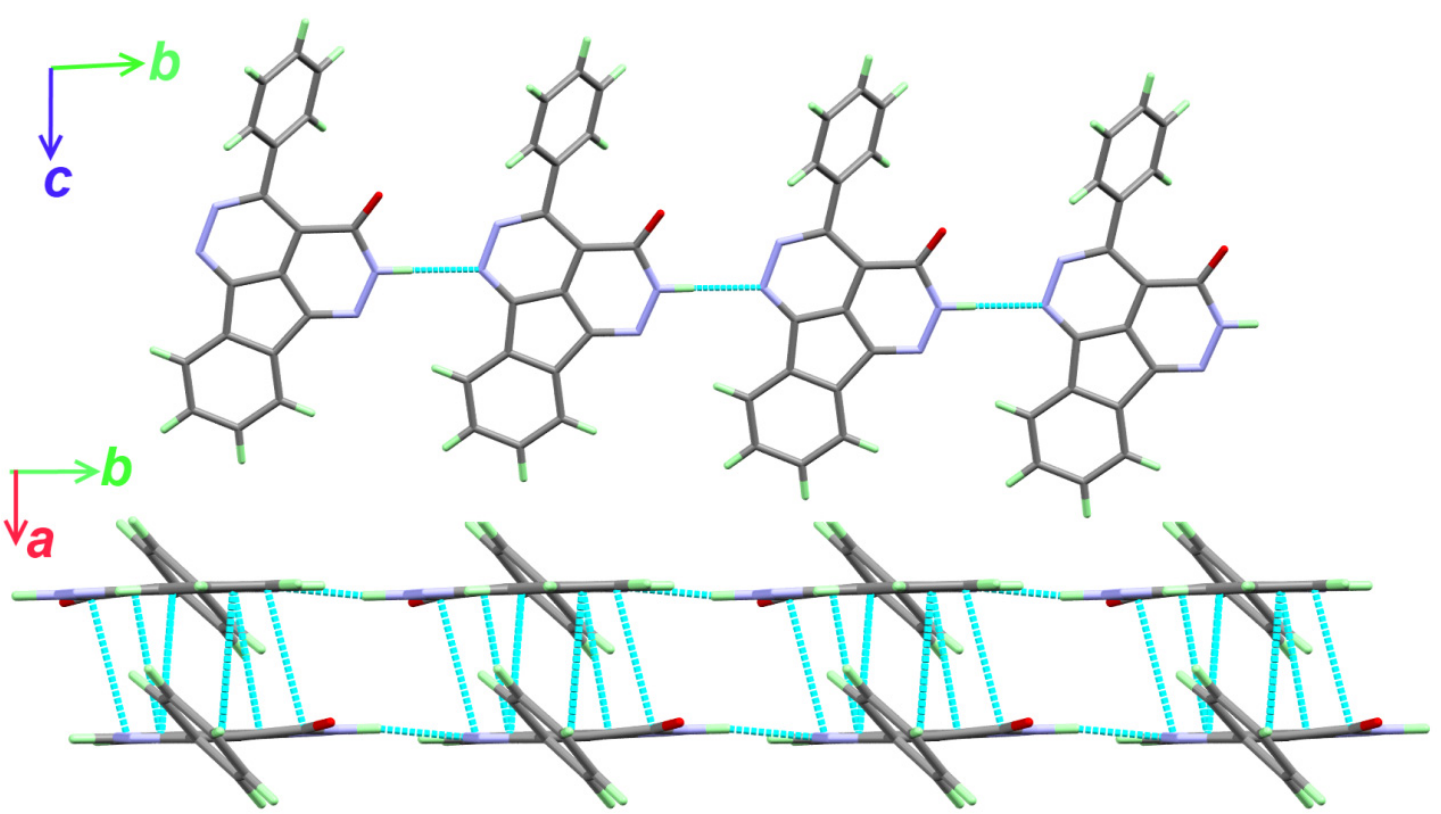

Figure 3. Packing via $\mathrm{N}-\mathrm{H} \ldots \mathrm{N}$ hydrogen bonds and $\pi-\pi$ stacking (lower) in 2.

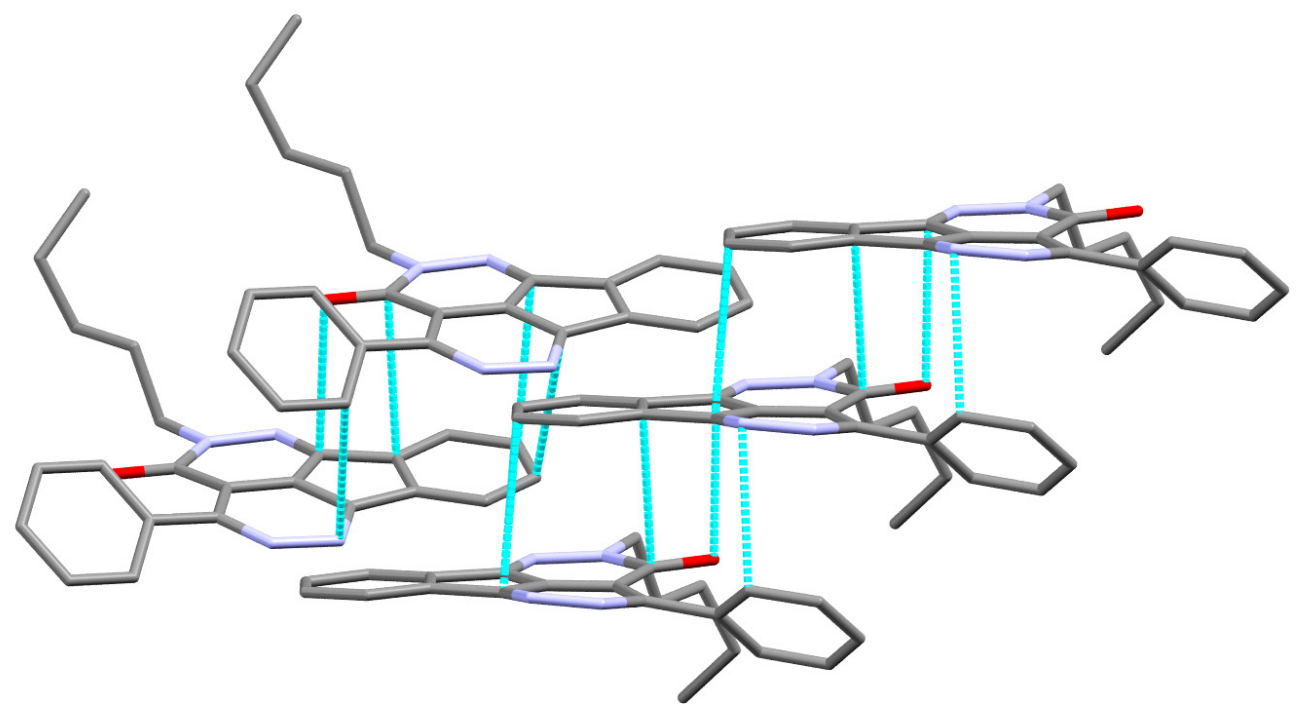

Figure 4. $\pi-\pi$ stacking (lower) in 2.

\subsection{Analysis of Molecular Packing}

Each crystal has its characteristic Hirshfeld surfaces which shed the light on the important intermolecular interactions which play important role in the crystal stability. In Figure 5, the different mapped surfaces of compounds $\mathbf{2}$ and $\mathbf{6}$ are summarized. The $\mathrm{d}_{\text {norm }}$ indicated a number of red spots related to intermolecular contacts shorter than the $\mathrm{vdW}$ sadii sum of the interacting atoms. In compound $\mathbf{2}$, the most important contacts are 
the $\mathrm{O} \ldots \mathrm{H}, \mathrm{N} \ldots \mathrm{H}, \mathrm{C} \ldots \mathrm{N}$ and $\mathrm{C} \ldots \mathrm{C}$ interactions. On the other hand, the $\mathrm{N} \ldots \mathrm{H}$, C ... N, C . . C, C . . O and H .. H interactions are the most important. Summary of these short contacts and the corresponding interaction distances are depicted in Table 5. The results revealed very well the presence of large number of $C \ldots C$ and $C \ldots N$ contacts in both compounds which confirm the presence of $\pi-\pi$ stacking interactions. Generally, these contacts occurred at longer interaction distances in 2 compared to 6 . In addition, the red/blue triangles in the shape index and large green area in curvedness are other evidences on the presence of $\pi-\pi$ stacking interactions (region D in Figure 5).

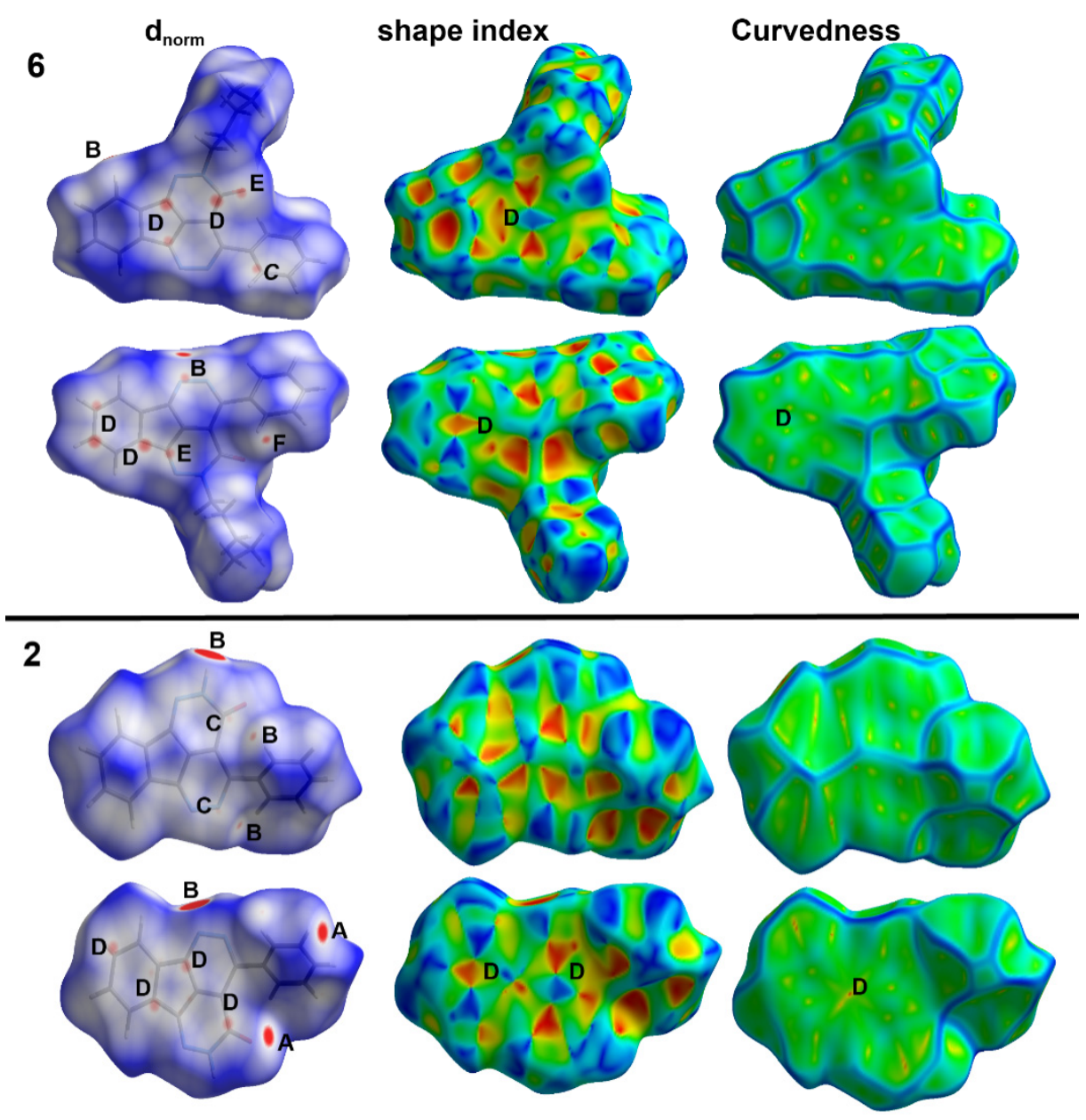

Figure 5. Hirshfeld maps of compounds 2 and 6. The most important interactions are (A) O ... H, (B) $\mathrm{N} \ldots \mathrm{H}$, (C) C . N , (D) C . C , (E) C . . O, and (F) H . . H.

Table 5. Short contacts in compounds 2 and 6.

\begin{tabular}{cccc}
\hline Contact & Distance & Contact & Distance \\
\hline & $\mathbf{2}$ & & $\mathbf{6}$ \\
$\mathrm{N} 1 \ldots \mathrm{H} 1$ & 1.911 & $\mathrm{~N} 2 \ldots \mathrm{H} 13$ & 2.446 \\
$\mathrm{~N} 2 \ldots \mathrm{H} 14$ & 2.584 & $\mathrm{C} 5 \ldots \mathrm{N} 2$ & 3.195 \\
$\mathrm{O} 1 \ldots \mathrm{H} 17$ & 2.405 & $\mathrm{C} 11 \ldots \mathrm{C} 8$ & 3.344 \\
$\mathrm{C} 10 \ldots \mathrm{N} 2$ & 3.227 & $\mathrm{C} 12 \ldots \mathrm{C} 15$ & 3.303 \\
$\mathrm{C} 1 \ldots \mathrm{C} 7$ & 3.387 & $\mathrm{C} 15 \ldots \mathrm{C} 18$ & 3.301 \\
$\mathrm{C} 1 \ldots \mathrm{C} 8$ & 3.378 & $\mathrm{H} 1 \ldots \mathrm{H} 1$ & 3.158 \\
$\mathrm{C} 3 \ldots \mathrm{C} 10$ & 3.334 & & 2.108 \\
C6 . C9 & 3.337 & & \\
\hline
\end{tabular}


On the other hand, analysis of the fingerprint plot gave a quantitative summary for all intermolecular contacts occurred in the crystal structure of compounds $\mathbf{2}$ and $\mathbf{6}$ (Figure 6).The decomposition of the fingerprint plot gave a quantitative summary for all contacts that occurred in the crystal structures of compounds $\mathbf{2}$ and $\mathbf{6}$ (Figure 7). It is clear that the most frequent contacts in both compounds are the $\mathrm{H} \ldots \mathrm{H}$ interactions. The percentages of $\mathrm{H}$... H interactions are 53.6 and $32.4 \%$ in compounds 2 and 6 , respectively. The shortest $\mathrm{H}$... H contacts in 6 are $\mathrm{H} 1$... H1 with interaction distance of $2.108 \AA$. In 2, all $\mathrm{H} \ldots \mathrm{H}$ contacts are significantly long and are considered of less importance compared to compound 6. The second most frequent contacts are the $\mathrm{C} \ldots \mathrm{H}$ interactions which comprised 15.9 and $23.1 \%$ from the whole interactions occurred in the crystal of $\mathbf{2}$ and $\mathbf{6}$, respectively. In compound 2 , the percentages of the important $\mathrm{O} \ldots \mathrm{H}, \mathrm{N} \ldots \mathrm{H}, \mathrm{C} \ldots \mathrm{N}$ and C .. C interactions are $3.5 \%, 13.6 \%, 2.2 \%$, and $8.3 \%$, respectively. Both $\mathrm{O} \ldots \mathrm{H}$ and $\mathrm{N}$... H contacts appeared as sharp spikes in the fingerprint plot (Figure 6). As a result, these interactions are considered strong and play an important role in the crystal stability of 2 and the $\pi-\pi$ stacking interactions as well. The spikes of the $\mathrm{N} \ldots \mathrm{H}$ and $\mathrm{O} \ldots \mathrm{H}$ interactions in $\mathbf{6}$ are less sharp, indicating weaker interactions than those that occurred in $\mathbf{2}$. The percentages of the $\mathrm{O} \ldots \mathrm{H}, \mathrm{N} \ldots \mathrm{H}, \mathrm{C} \ldots \mathrm{N}$ and $\mathrm{C} \ldots \mathrm{C}$ interactions in 6 are 9.0, 15.8, 7.3 , and $9.1 \%$, respectively.

\section{6}
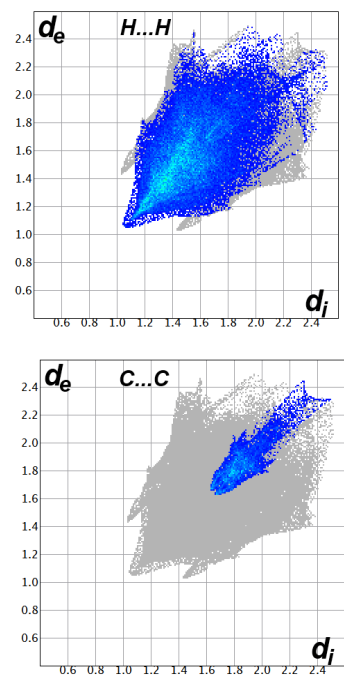

$\boldsymbol{d}_{i}$
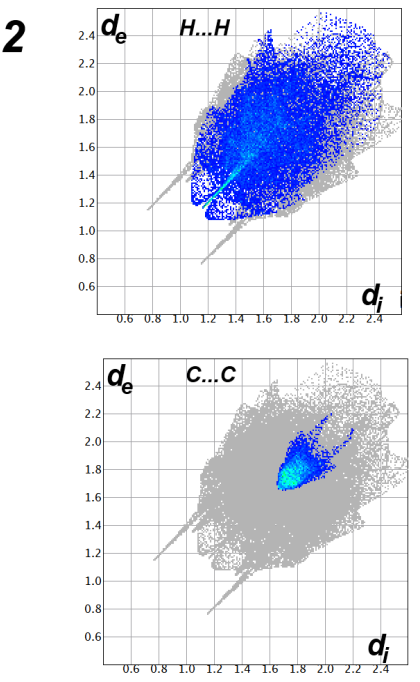
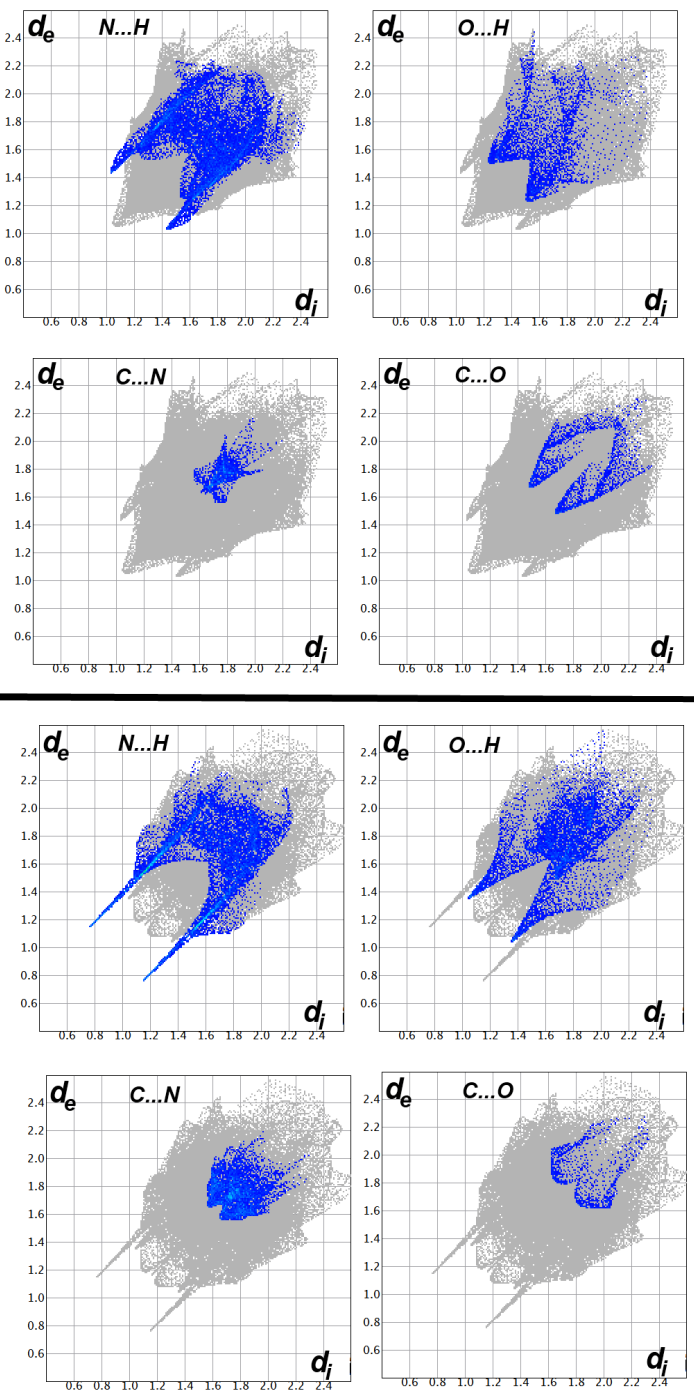

Figure 6. Decomposed fingerprint plots in compounds 2 and $\mathbf{6}$. 


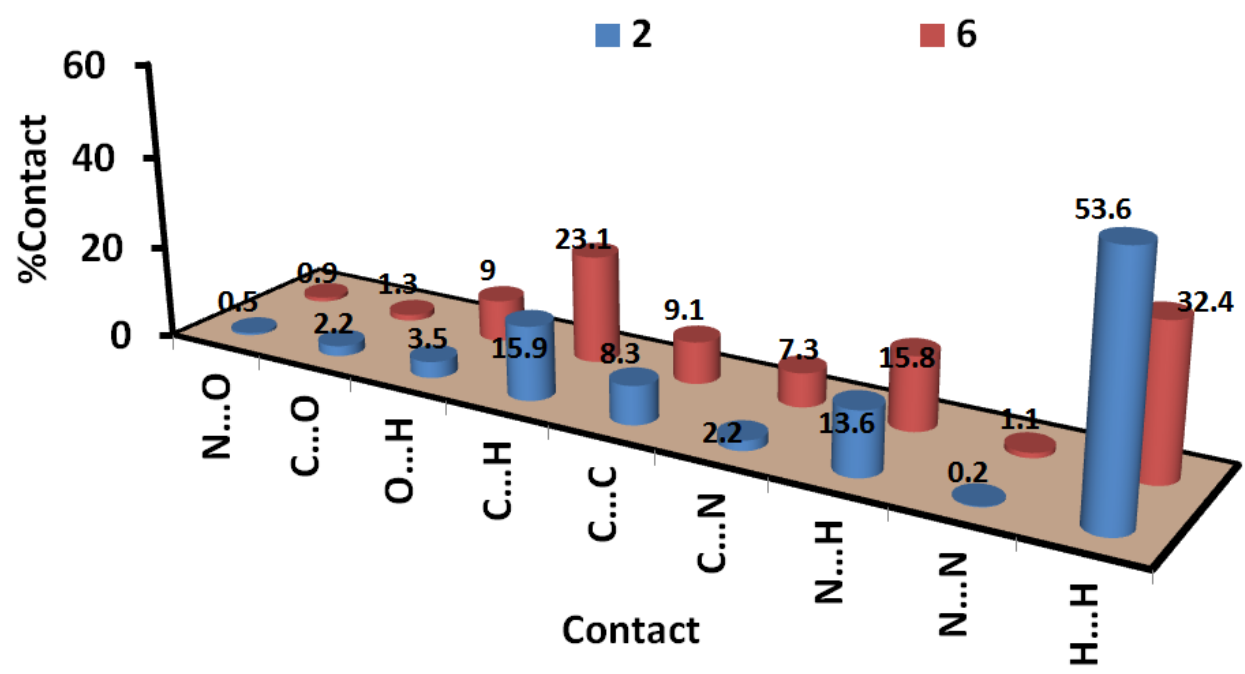

Figure 7. All intermolecular interactions in compounds 2 and $\mathbf{6}$.

\section{Conclusions}

In conclusion, this manuscript introduced a direct one-pot method for obtaining 4phenyl-1,2,5,6-tetraazafluoranthen-3(2H)-one from triketo ester to validate the application of our previous published method. Herein, another $\beta$-ketoester (ethyl benzoylacetate) was used for obtaining the triketo ester which used for the synthesis of tatraazafluoranthenone. On reaction with Michael acceptors like acrylonitrile, aza-Michael addition was produced. Alkylation of tetraazafluoranthen-3(2H)-one in the presence of $\mathrm{K}_{2} \mathrm{CO}_{3}$ led to $\mathrm{N}$-alkylation, not $\mathrm{O}$-alkylation, this evidence was deduced from the ${ }^{13} \mathrm{C} \mathrm{NMR}$ signal around $50.00 \mathrm{ppm}$ for $\mathrm{NCH}_{2}$. Hydrazinolysis of 4-phenyl-1,2,5,6-tetraazafluoranthen-3(2H)-one ester led to hydrazide formation which is converted to thiosemicarbazide by reaction with phenyl isothiocyanate. Different intermolecular interactions that occurred in the crystal structures of compound 2 and 6 were analyzed using Hirshfled calculations.

Supplementary Materials: The following supporting information can be downloaded at: https:// www.mdpi.com/article/10.3390/cryst12020262/s1, X-ray structure determinations; Figure S1: ${ }^{1} \mathrm{H}$ NMR of 2; Figure S2: ${ }^{13} \mathrm{C}$ NMR of 2; Figure S3: ${ }^{1} \mathrm{H}$ NMR of 3; Figure S4: ${ }^{13} \mathrm{C}$ NMR of 3; Figure S5: ${ }^{1} \mathrm{H}$ NMR of 4; Figure S6: ${ }^{13} \mathrm{C}$ NMR of 4; Figure S7: ${ }^{1} \mathrm{H}$ NMR of 5; Figure S8: ${ }^{13} \mathrm{C}$ NMR of 5; Figure S9: ${ }^{1} \mathrm{H}$ NMR of 6; Figure S10: ${ }^{13} \mathrm{C}$ NMR of 6; Figure S11: ${ }^{1} \mathrm{H}$ NMR of 7; Figure S12: ${ }^{13} \mathrm{C}$ NMR of 7; Figure S13: ${ }^{1} \mathrm{H}$ NMR of 8; Figure S14: ${ }^{13} \mathrm{C}$ NMR of 8; Figure S15: ${ }^{1} \mathrm{H}$ NMR of 9; Figure S16: ${ }^{13} \mathrm{C}$ NMR of 9.

Author Contributions: Conceptualization, A.T.A.B., A.B. and A.A.M.S.; methodology, M.S. and A.A.M.S.; software, M.H. and S.M.S.; validation, M.S. and A.A.M.S.; formal analysis, A.T.A.B., S.M.S. and M.H.; investigation, A.T.A.B. and A.A.M.S.; resources, A.T.A.B.; data curation, A.T.A.B. and M.H.; writing-original draft preparation, A.T.A.B., A.B.; writing-review and editing, A.B.; visualization, A.M.A.-M.; supervision, A.B.; project administration, M.S. and A.M.A.-M.; funding acquisition, A.M.A.-M. All authors have read and agreed to the published version of the manuscript.

Funding: This research was funded by Researchers Supporting Project (RSP2022R427), King Saud University, Riyadh, Saudi Arabia.

Institutional Review Board Statement: Not applicable.

Informed Consent Statement: Not applicable.

Data Availability Statement: Not applicable.

Acknowledgments: The authors would like to extend their sincere appreciation to the Researchers Supporting Project (RSP2022R427), King Saud University, Riyadh, Saudi Arabia.

Conflicts of Interest: The authors declare no conflict of interest. 


\section{References}

1. Stępień, M.; Gońka, E.; Żyła, M.; Sprutta, N. Heterocyclic nanographenes and other polycyclic heteroaromatic compounds: Synthetic routes, properties, and applications. Chem. Rev. 2017, 117, 3479-3716. [CrossRef]

2. Feng, X.; Pisula, W.; Müllen, K. Large polycyclic aromatic hydrocarbons: Synthesis and discotic organization. Pure Appl. Chem. 2009, 81, 2203-2224. [CrossRef]

3. Plunkett, K. What about the five-membered ring? Cyclopentafused polycyclic aromatic hydrocarbons as a building block for functional materials. Synlett 2013, 24, 898-902. [CrossRef]

4. Lee, Y.H.; Wu, T.C.; Liaw, C.W.; Wen, T.C.; Feng, S.W.; Lee, J.J.; Guo, T.F. Non-doped active layer, benzo [k] fluoranthene-based linear acenes, for deep blue-to green-emissive organic light-emitting diodes. Org. Electron. 2013, 14, 1064-1072. [CrossRef]

5. Du, L.; King, J.B.; Cichewicz, R.H. Chlorinated polyketide obtained from a Daldinia sp. Treated with the epigenetic modifier suberoylanilide hydroxamic Acid. J. Nat. Prod. 2014, 77, 2454-2458. [CrossRef] [PubMed]

6. Brauers, G.; Ebel, R.; Edrada, R.; Wray, V.; Berg, A.; Gräfe, U.; Proksch, P. Hortein, a new natural product from the fungus Hortaea werneckii associated with the Sponge Aplysina aerophoba. J. Nat. Prod. 2001, 64, 651-652. [CrossRef]

7. Goel, A.; Sharma, A.; Kathuria, M.; Bhattacharjee, A.; Verma, A.; Mishra, P.R.; Nazir, A.; Mitra, K. New fluoranthene FLUN-550 as a fluorescent probe for selective staining and quantification of intracellular lipid droplets. Org. Lett. 2014, 16, 756-759. [CrossRef]

8. Gu, X.; Luhman, W.A.; Yagodkin, E.; Holmes, R.J.; Douglas, C.J. Diarylindenotetracenes via a selective cross-coupling/C-H functionalization: Electron donors for organic photovoltaic cells. Org. Lett. 2012, 14, 1390-1393. [CrossRef] [PubMed]

9. Wu, H.; Fang, R.; Tao, J.; Wang, D.; Qiao, X.; Yang, X.; Hartl, F.; Li, H. Diacenaphthylene-fused benzo [1, 2-b: 4, 5-b'] dithiophenes: Polycyclic heteroacenes containing full-carbon five-membered aromatic rings. Chem. Commun. 2017, 53, 751-754. [CrossRef]

10. Rice, J.E.; Cai, Z.W. An intramolecular arene-triflate coupling reaction for the regiospecific synthesis of substituted benzofluoranthenes. J. Org. Chem. 1993, 58, 1415-1424. [CrossRef]

11. Reisch, H.A.; Bratcher, M.S.; Scott, L.T. Imposing curvature on a polyarene by intramolecular palladium-catalyzed arylation reactions: A simple synthesis of dibenzo[a,g]corannulene. Org. Lett. 2000, 2, 1427-1430. [CrossRef]

12. Wegner, H.A.; Scott, L.T.; de Meijere, A. A new Suzuki-Heck-Type coupling cascade: Indeno [1, 2, 3]-annelation of polycyclic aromatic hydrocarbons. J. Org. Chem. 2003, 68, 883-887. [CrossRef] [PubMed]

13. $\mathrm{Wu}, \mathrm{Y} .-\mathrm{T}$; Linden, A.; Siegel, J.S. Formal $[(2+2)+2]$ and $[(2+2)+(2+2)]$ nonconjugated dienediyne cascade cycloadditions. Org. Lett. 2005, 7, 4353-4355. [CrossRef] [PubMed]

14. Pascual, S.; Bour, C.; de Mendoza, P.; Echavarren, A.M. Synthesis of fluoranthenes by hydroarylation of alkynes catalyzed by gold (I) or gallium trichloride. Beilstein J. Org. Chem. 2011, 7, 1520-1525. [CrossRef] [PubMed]

15. Chen, X.; Lu, P.; Wang, Y. Four iodine-mediated electrophilic cyclizations of rigid parallel triple bonds Mapped from 1, 8Dialkynylnaphthalenes. Chem.-Eur. J. 2011, 17, 8105-8114. [CrossRef]

16. Kawasumi, K.; Mochida, K.; Kajino, T.; Segawa, Y.; Itami, K. Pd(OAc) $)_{2} /$ o-Chloranil/M(OTf $)_{n}$ : A catalyst for the direct C-H arylation of polycyclic aromatic hydrocarbons with boryl-, silyl-, and unfunctionalized arenes. Org. Lett. 2012, 14, 418-421. [CrossRef]

17. Chang, M.-Y.; Lee, T.-W.; Wu, M.-H. Polyphosphoric acid promoted synthesis of 10,11-Dihydrobenzo[j]fluoranthen-12-one. Org. Lett. 2012, 14, 2198-2201. [CrossRef]

18. Zhou, J.; Yang, W.; Wang, B.; Ren, H. Friedel-Crafts arylation for the formation of Csp2-Csp2 bonds: A route to unsymmetrical and functionalized polycyclic aromatic hydrocarbons from aryl triazenes. Angew. Chem. Int. Ed. 2012, 51, 12293-12297. [CrossRef]

19. Ogawa, N.; Yamaoka, Y.; Yamada, K.-I.; Takasu, K. Synthesis of $\pi$-extended fluoranthenes via a KHMDS-promoted anionic-radical reaction cascade. Org. Lett. 2017, 19, 3327-3330. [CrossRef] [PubMed]

20. Chiechi, R.C.; Tseng, R.J.; Marchioni, F.; Yang, Y.; Wudl, F. Efficient Blue-Light-Emitting Electroluminescent Devices with a Robust Fluorophore: 7,8,10-Triphenylfluoranthene. Adv. Mater. 2006, 18, 325-328. [CrossRef]

21. Yan, Q.; Zhou, Y.; Ni, B.-B.; Ma, Y.; Wang, J.; Pei, J.; Cao, Y. Organic semiconducting materials from sulfur-hetero benzo[k]fluoranthene derivatives: Synthesis, photophysical properties, and thin film fransistor fabrication. J. Org. Chem. 2008, 73, 5328-5339. [CrossRef] [PubMed]

22. Goel, A.; Kumar, V.; Chaurasia, S.; Rawat, M.; Prasad, R.; Anand, R.S. Synthesis, electrochemical and optical properties of stable yellow fluorescent fluoranthenes. J. Org. Chem. 2010, 75, 3656-3662. [CrossRef] [PubMed]

23. Ding, L.; Ying, H.-Z.; Zhou, Y.; Lei, T.; Pei, J. Polycyclic imide derivatives: Synthesis and effective tuning of lowest unoccupied molecular orbital levels through molecular engineering. Org. Lett. 2010, 12, 5522-5525. [CrossRef] [PubMed]

24. Quimby, J.M.; Scott, L.T. Expanding the Suzuki-Heck-type coupling cascade: A new indeno [1, 2, 3]-annelation of polycyclic aromatic hydrocarbons. Adv. Synth. Catal. 2009, 351, 1009-1013. [CrossRef]

25. Yamaguchi, M.; Higuchi, M.; Tazawa, K.; Manabe, K. Three-step synthesis of fluoranthenes through Pd-catalyzed inter-and intramolecular C-H arylation. J. Org. Chem. 2016, 81, 3967-3974. [CrossRef]

26. Pal, S.; Metin, O.; Turkmen, Y.E. Synthesis of fluoranthene derivatives via tandem Suzuki-Miyaura and intramolecular C-H Arylation reactions under both homogeneous and heterogeneous catalytic conditions. ACS Omega 2017, 2, 8689-8696. [CrossRef]

27. Koutentis, P.A.; Loizou, G.; Lo Re, D. Synthesis of triazafluoranthenones via silver (I)-mediated nonoxidative and oxidative intramolecular palladium-catalyzed cyclizations. J. Org. Chem. 2011, 76, 5793-5802. [CrossRef]

28. Pathak, S.; Debnath, K.; Pramanik, A. Silica sulfuric acid: A reusable solid catalyst for one pot synthesis of densely substituted pyrrole-fused isocoumarins under solvent-free conditions. Beilstein J. Org. Chem. 2013, 9, 2344-2353. [CrossRef] 
29. Boraei, A.T.; Ghabbour, H.A.; Sarhan, A.A.; Barakat, A. Expeditious green synthesis of novel 4-methyl-1, 2, 5, 6tetraazafluoranthen-3 $(2 H)$-one analogue from ninhydrin: N/S-alkylation and aza-Michael addition. ACS Omega 2020, 5, 5436-5442. [CrossRef]

30. Boraei, A.T.A.; Soliman, S.M.; Haukka, M.; Salama, E.E.; Sopaih, M.; Barakat, A.; Sarhan, A.A.M. Straightforward green synthesis of indeno-furan carboxylates from ninhydrin and $\beta$-ketoesters: X-Ray crystal structure, Hirshfeld and DFT investigations. J. Mol. Struct. 2022, 1255, 132433. [CrossRef]

31. Peet, N.P.; Huber, E.W.; Huffman, J.C. Reaction of ninhydrin with $\beta$-dicarbonyl compounds. J. Heterocyclic Chem. $1995,32,33-41$. [CrossRef] 